\title{
Shortcomings in Treatment of Epilepsy
}

\author{
Jos Utama ${ }^{*}$, Evi Setiadi ${ }^{*}$ Wilmar Musram ${ }^{\star \star}$
}

\begin{abstract}
Abstrak
Dalam usaha mempertinggi efektivitas hasil pengobatan pasien epilepsi, telah diteliti faktor-faktor ekstrinsik non-medik, seperti lingkungan, pendidikan dan status gizi serta pengaruh stres dalaim hidup pasien sehari-hari. Telah diperiksa sebanyak 103 pasien epilepsi yang berobat di polikliniksaraf RSCM, terdiri atas 46 pria dan 57 wanita, dengan usia 11-71 tahun. Masa pengobatan berkisar antara nol bulan sampai lebih dari dua puluh tahun. Jenis obat yang digunakan terutama fenobarbital (76,6\%), difantoin (35\%) dan karbamazepin (18,3\%). Suplementasi vit. B kompleks (10\%) atau asam folat khusus (20\%) jarang diberikan. Ternyata bahwa status pendidikan pasien rata-rata berkisar antara taraf SD dan perbatasan antara SMP-SMA, dengan latar belakang sosial-ekonomis rendah sampai sedang dengan status gizi yang kurang termasuk defisiensi vit. B1, B6, asam folat dan ion Ca. Status vit. B12 yang masih dalam batas normal belum dapat diterangkan. Keadaan stres, baik fisik maupun mental, pada umumnya sangat tinggi, yaitu rata-rata $70 \%$. Telah diketahui pula bahwa vit. B6 sebagai ko-faktor mutlak diperlukan dalam sintesis asam gamma aminobutirat (GABA), suatu neurotransmiter penghambat yang penting. Sama halnya dengan ion Ca yang esensial dalam pelbagai proses metabolik sel neuron. Kesimpulannya ialah bahwa pengobatan epilepsi yang bijaksana, seyogyanya harus memperhatikan status gizi dan faktor ekstrinsik pasien, di samping pemberian obat antiepilepsi yang sesuai, terufama pada kasus epilepsi refrakter.
\end{abstract}

\begin{abstract}
In order to enhance the efficacy of treatment of epilepsy, we take into consideration the effects of the non-medical extrinsic factors, like environment, education and nutritional status together with all kinds of daily stress activities. A number of 103 epilepric parients, from the outpatient department of Dr. Cipto Mangunkusumo Hospital, consisting of 46 males and 57 females, ages 11-7I years with a treament period of zero months to more than 20 years are selected. The most commonly used drug is phenobarbital (76,6\%), followed by diphantoin (35\%) and carbamazepine (18,3\%), while the B-complex vitamins (10\%) or isolated folic acid (20\%) supplementation are only rarely given. The general education level of the patients varies from elementary school to senior high-school, wirh a low to moderate socio-economical background and a low status of vit. BI, B6, Folic acid and Ca ion. For the normal vit. BI2 status of the patients we have no explanation. The existence of physical and mental stress is extremely high, with a general record of more than $70 \%$. The need of vit. B6 as co-factor in the synthesis of gamma aminobutyric acid (GABA), an important inhibiting neurotransmitter in neuronal transmission, is well known, just as Ca ion is essential in cell merabolism. Thus, an optimal epileptic treatment should not only' include an appropriate drug strategy' and its compliances but also an overall dynamic, well balanced conside ration of the whole patient's lifestyle including dietary requirements, expecially in refractory epilepric cases.
\end{abstract}

Key words : epilepsy, neurotransmitters, nutrition and vitamins

\section{INTRODUCTION}

As a rule, medical treatment of epileptic patients has been limited to the prescription of common antiepileptic drugs. Only in a small number of cases mostly in failures - more attention has been paid to secondary conditions, like strenuous and emotional factors, environment and lifestyle; but a real scientific investigation of the nutritional status of the patients has never been done.

Prominent figures in ancient epilepsy, in the beginning of our century, have already stressed the importance of nutritional factors in eliminating epileptic seizures, but the idea of a ketogenic diet (rich in fatty substances), together with a regular lifestyle has never been well formulated.

\footnotetext{
* Department of Neurology, Faculty of Medicine, University of Indonesia/Dr. Cipto Mangunkusumo Hospital, Jakarta, Indonesia ** Department of Biochemistry, Faculty of Medicine, University of Indonesia, Jakarta, Indonesia
} 
Recent developments and findings in the field of biotechnology and medical research have stimulated us to take into serious consideration the influences of secondary or external factors in epileptics, next to existing endogenic factors. Environmental factors, strenuous conditions, nutrition, vitamins, neurotransmitters, minerals and other possibilities that could stimulate and enhance the efficacy of the common antiepileptic arsenal became our focus of attention.

Another undeniable fact is that until now only a part of the seizures (approximately $80 \%$ ) are satisfactorily controlled by antiepileptic drugs. However it is an unstable and dynamic situation, depending upon the optimal condition of the patient.

A relatively small part of the patients seems to be unresponsive to oral antiepileptic treatment, single or in combined doses, and are called refractory or intractable epileptic cases. Only a part of these refractory cases with well defined organic structures could be treated successfully by invasive operative methods.

On the other side, recent experiments have confirmed the key functions of vit. $\mathrm{B} 6$ and $\mathrm{Ca}^{2+}$ in the process of muscle and cell metabolism, not only clinically but also electrophysiologically in EEG and EMG recordings.

Based on these findings, investigations concerning these accompanying extrinsic factors - like vitamins, $\mathrm{Ca}^{2+}$, stress - in epileptics were done, in order to achieve better therapeutic results.

\section{Hypothesis}

Shortcomings or failure in treatment of epilepsy are not only related to direct medical treatment but also to secondary extrinsic factors, like patient's environment, nutritional, educational state and irregular unbalanced lifestyle.

\section{Objectives}

To assess the secondary extrinsic factors in epileptic patients, like socio-economic and nutritional status together with the existence of stress factors.

\section{MATERIALS AND METHODS}

The material consists of 103 epileptic patients, 46 males and 57 females, ages 11-71 years, selected from the neurological outpatient department of Dr. Cipto Mangunkusumo Hospital, Jakarta. The control group, 101 healthy persons, are recruited from medical students and medical personnel, ages between 18-70 years.
The examination consists of :

Clinical neurology, biochemistry, routine EEG recording and peripheral blood examination while drug monitoring, X-ray or CT scan are only performed in selected cases.

Due to technical factors the procedure is divided into two stages :

Stage I : determination of vit. B1 status in a randomized group of 20 patients.

Stage II : determination of vit. B6, B12, Folicacid and $\mathrm{Ca}^{2+}$ status of two groups of patients, consisting of 20 newcomers and 63 chronic epileptics.

The patients are interviewed using a specially prepared check list form, covering personal data together with the patient's social and educational level and occupation, food consumption and stress factors.

The vit. B1 status is expressed in the Thiamine Pyrophosphate (TPP) effect which is determined by the method of Schouten, a modification of the Dreyfus test. ${ }^{1}$ The erythrocyte hemolysate is incubated with and without addition of TPP. The increased transketolase (TK) activity resulting from the addition of TPP is inversely related to thiamine depletion. The TPP effect is the percentage increase of TK activity after addition of TPP.'

Vitamin B6 status is determined by the erythrocyte aminotransferase (EAT) activity test and expressed in the Coefficient of EAT activation

$$
\text { (CA), i.e. the ratio } \frac{\begin{array}{c}
\text { EAT activity with addition of PLP } \\
\text { (pyridoxalphosphate) }
\end{array}}{\text { EAT activity without addition of PLP }}
$$

The EAT activity is estimated using the Granutest 25 ASAT Tris Merck kit no. 12162 and 12165. In vitamin B6 deficiency EAT activity decreases, resulting in a higher $C A$ value. The higher the $C A$ value, the more severe the deficiency. ${ }^{2}$

Plasma vitamin B12 and Folic acid are determined simultaneously using the DPC (Diagnostic Product Corporation) Solid Phase no boil Radioimmunoassay kit.

For the $\mathrm{Ca}^{2+}$ determination, venous blood collected in a heparin tube, is aspirated into the $\mathrm{ICA}_{2}$ apparatus (ion selective electrode), providing the $\mathrm{Ca}^{2+}$ concentration at the $\mathrm{pH}$ of the sample and the converted $\mathrm{Ca}^{2+}$ concentration at $\mathrm{pH} 7.4$.

\section{RESULTS}

The vitamin and $\mathrm{Ca}$ ion status of the epileptic patients are shown in Table 1. Statistical analysis shows a significant difference between the TPP effect of the epileptic patients and the control group $(p<0.001)$. 
The Coefficient of EAT Activation (CA) of the epileptic patients and the control group are compared. Statistical analysis shows a significant difference between both groups $(p<0.001)$, indicating a vitamin B6 deficiency in the epileptic patients.

Comparing the $\mathrm{Ca}$ ion status of the epileptic patients with the references values, a significant $\mathrm{Ca}$ ion deficiency is found in the epileptic group.

The vit. B12 status in all the epileptic patients, 20 newcomers and 20 chronic cases is normal, except in one case of chronic epilepsy, treated with luminal $2 \times$ $30 \mathrm{mg}$ daily. The FA status is decreased in $47.4 \%$ of the examined patients.

In general we have found no significant differences in the biochemistry values of the chronic epileptic patients and the newcomers, except for a slight decrease in the FA status in the chronic epileptics.

Patients background information obtained by interview is shown in table 2 .

\section{DISCUSSION}

Although we often do not know what the mechanism of epileptogenesis is, yet continuous research has provided more understanding in experimental epilepsies. Changes in extrinsic factors (environment, ionic concentrations) play an important role on the course of seizure activity next to the intrinsic factors (pace maker cells, synaptic transmission).

Under normal conditions, cell membranes have a resting potential due to the differences in ionic concentration inside and outside the cells. The main factors for sustaining this status of polarization are the selective semipermeability of the cell membrane and the dynamic functions of the ionic pumps. Changes in electrolytes or ionic concentrations of blood plasma, will cause an alteration in electrical activity of the cell membranes, called paroxysmal depolarization shift (PDS). Extracellular $\mathrm{Ca}^{2+}$ and $\mathrm{Na}^{+}$will enter the cell, while intracellular $\mathrm{K}^{+}$is shifting outwards. Prolonged depolarization or seizure activity will lead to a dysfunction of the ionic pumps, resulting in cell oedema and irreversibel damage.

Apart from control through voltage and repolarizing $\mathrm{K}^{+}$currents, intracellular $\mathrm{Ca}^{2+}$ accumulation contributes to inactivation of persistent $\mathrm{Ca}^{2+}$ currents. ${ }^{3}$ This control is further enhanced by a number of neurotransmitters (NT) such as gamma aminobutyric acid (GABA) and norepinephrine (NE), which depress both persistent and transient $\mathrm{Ca}^{2+}$ currents. ${ }^{4,5} \mathrm{GABA}$ is an important inhibitory NT in the human body, dysfunction of GABA will result in destabilization of neuron function.

Pyridoxal-5-phosphate (PLP), the active form of vit. B6, acts as a cofactor in different reactions of amino acid metabolism.

PLP participation in amino acid decarboxylation is essential for the synthesis of NTs like GABA. A decrease or increase of vit. B6 in GABA metabolism should be considered as a possible cause of seizure activity. ${ }^{7,8,9}$

Experimental work with PLP injection intra ventricularly, has resulted in the production of tonic clonic seizures in mice. ${ }^{10}$

Kryzhanovski and Shandra have found that a combination of the vitamins nicotinamide, vit. B6 and alfa tocoferol (vit. E) functionally has a much better antiepileptic effect than the isolated vitamins. The enhanced efficacy of the combined treatment with nicotinamide, vit. B6 and vit. E together with an anti epileptic drug, is shown by the fact that a significant smaller dose of the anti epileptic drug is required. ${ }^{11}$

Table 1. Vitamin and $\mathrm{Ca}$ ion status

\begin{tabular}{|c|c|c|c|c|c|}
\hline & $\begin{array}{l}\text { Vit. B1 status } \\
\text { (\% TPP effect) }\end{array}$ & $\begin{array}{c}\text { Vit. B6 status } \\
\text { (activation } \\
\text { coefficient) }\end{array}$ & $\begin{array}{c}\text { Blood } \mathrm{Ca}^{2+} \text { at } \mathrm{pH} 7.4 \\
\mathrm{mmol} / \mathrm{L}\end{array}$ & $\begin{array}{c}\text { Plasma Folic acid } \\
\mathrm{ng} / \mathrm{ml}\end{array}$ & $\begin{array}{c}\text { Plasma vit. B12 } \\
\mathrm{pg} / \mathrm{ml}\end{array}$ \\
\hline \multicolumn{6}{|l|}{ Epileptic patients } \\
\hline newcomers & & $1.77 \pm 0.38(n=20)$ & $1.13 \pm 0.04(n=20)$ & $4.33 \pm 2.91(n=18)$ & $489 \pm 288(n=18)$ \\
\hline Chronic patients & & $1.66 \pm 0.51 \quad(n=63)$ & $1.12 \pm 0.04(n=63)$ & $4.61 \pm 3.32(n=20)$ & $538 \pm 40(n=20)$ \\
\hline whole group & $48.8 \pm 26.4(n=20)$ & $1.69 \pm 0.48(n=83)$ & $1.13 \pm 0.04(n=83)$ & $4.47 \pm 3.05(n=38)$ & $514 \pm 308(n=38)$ \\
\hline Control group & $14.5 \pm 12.4(n=38)$ & $1.27 \pm 0.11(n=81)$ & & & \\
\hline $\begin{array}{l}\text { Reference value } \\
\text { range }\end{array}$ & & & $1.14-1.29$ & $3.0-17$ & $200-950$ \\
\hline
\end{tabular}

Note : Values in mean $\bar{x} \pm 1 S D$ 
Table 2. Extrinsic factors in epileptics

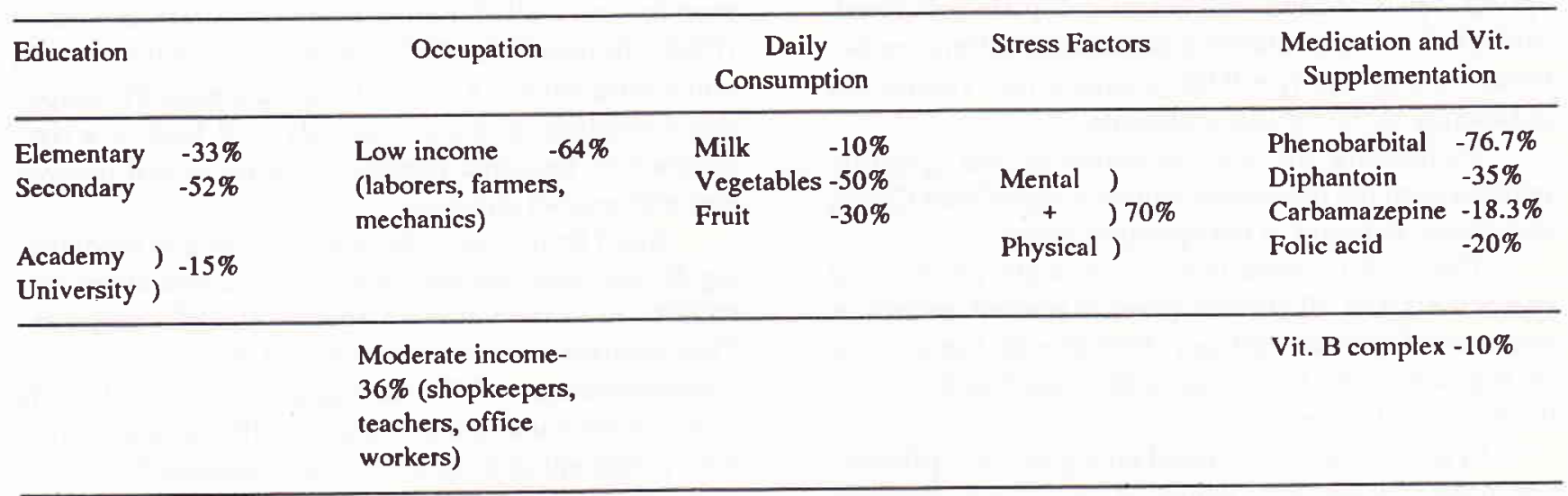

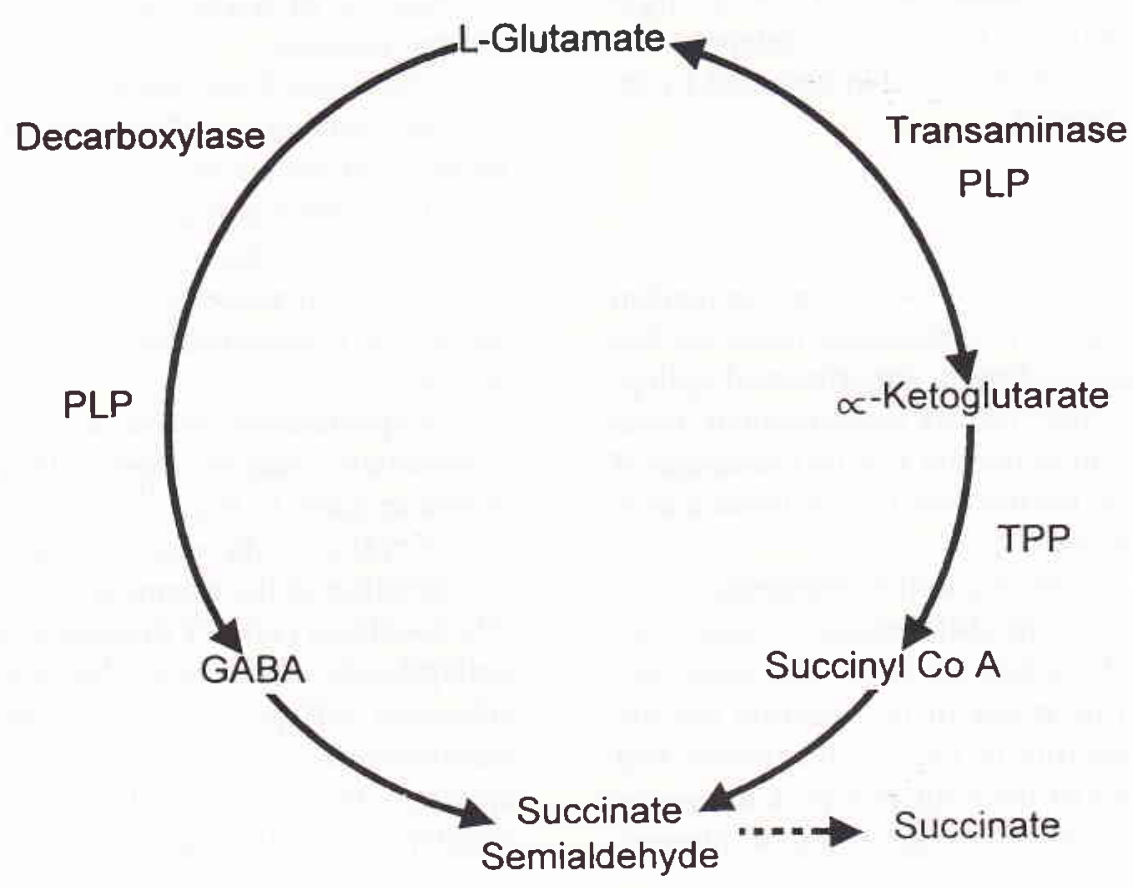

Figure I. Gamma aminobutyric acid synthesis and metabolism

Thus it is clear that unfavourable conditions like a deficiency in $\mathrm{Ca}^{2+}$, minerals, vitamins like $\mathrm{B} 6, \mathrm{~B} 1$, Folic acid and malnutrition as a whole, will worsen the epileptic state.

Research work concerning the absorption of anti epileptic drugs and intake of food, has proven that carbamazepine absorption, both in healthy persons and patients, is unaffected by food, whether it is rich in fat or rich in protein. 12

Neglected health care and an unresponsible way of life, will also weaken the body resistance, just like strenuous physical and mental conditions have a direct effect upon NT metbolism, both facilitating and inhibiting. Thus all these facts remind us that stress and other external factors are crucial problems for the epileptic patient.

Beside the extrinsic factors there are still the intrinsic factors to be considered, like the unstable synaptic transmission and the ectopic or pathologic pacemaker cells. An increased abnormal synaptic facilitation can result in seizure activity ${ }^{13,14}$ due to a lowered $\mathrm{Mg}^{2+}$ or to an increased $\mathrm{K}^{+}$concentration. The 
use of epileptic stimulants like picrotoxin is a frequent cause of seizures. The fact that seizure like activity develops when synaptic transmission between nerve cells is suppressed, shows that intrinsic membrane characteristics can determine seizure generation. ${ }^{15,16}$

Work on hippocampus slices have shown that certain cells, called pacemaker cells, in the hippocampus (the commissural associational neurons in the Ammon's horn) areas $\mathrm{CA} 1$ and $\mathrm{CA} 3$ and in the brainstem, have the intrinsic capability to generate bursts. However, whether a full blown seizure will develop depends also on the presence of a critical mass of affected neurons in other areas. These so called pacemaker cells possess the capability of synchronizing the activity of the whole population and the critical mass of affected neurons are recruited into ictal activity by recurrent excitatory collaterals, which is called biofeedback.

An interesting finding is the fact that intrinsic factors in epileptic patients are liable to alterations with the increase in age and with progressive polluting conditions. These clinical and structural changes are clearly observed in all neurophysiological recordings.

It is now generally accepted that both intrinsic as well as extrinsic factors are important milestones in the epileptic patient. An unstable personality with an undernourished condition is a vulnerable situation. We have confirmed the undernourishment and high stress conditions in the epileptic group and are of the opinion that the ideal treatment of epileptic patients is not only a pure medical problem but a well balanced package strategy, covering simultaneously the patients intrinsic and extrinsic shortcomings.

\section{CONCLUSIONS}

1. The extrinsic factors of the epileptic patients in the Cipto Mangunkusumo Hospital show a lot of shortcomings.

2. Epileptic patients show a deficiency in vit. B6, B1, $\mathrm{Ca}^{2+}$ and Folic acid (FA).

3. No difference in biochemistry values is found between the group of newcomers and the chronic epileptics, except for a slight decrease in the FA status in the chronic epileptics.

4. The combined treatment of extrinsic and intrinsic factors in epileptic patients in the Cipto Mangunkusumo Hospital should be more balanced and more dynamic.

5. An optimal epileptic treatment should not only include an appropriate drug strategy and its compliances but an overall dynamic, well balanced consideration of the whole patient's lifestyle including dietary requirements.

\section{REFERENCES}

1. Setiadi E, Musram W, Harnopidjati D, Djalil H. Efek TPP (Tiamin Pirofosfat) dan Konsumsi Vitamin B1 Sekelompok Mahasiswa. Maj Kedokt Indon 1991; 41:645-8.

2. Musram W. Penetapan Status Vitamin B6 dengan Uji Aktivitas Aminotransferase Eritrosit. Maj Kedokt Indon 1994; 44:154-7.

3. Eckert R, Chad JE. Inactivation of Ca channels. Prog Biophys Mol Biol 1984; 44:215-67.

4. Deisz RA, Lux HD. Gamma Aminobutyric acid induced depression of calcum currents of chick sensory neurons. Neurosci 1985; 56:205- 10.

5. Dunlap K, Fischbach GD. Neurotransmitters decrease the calcum conductance activated by depolarization of embryonic chick sensory neurons. J Physiol 1981; 317:51935.

6. Rodwell VW. Conversion of Amino Acids to Specialized Products. In : Murray RK et al.(ed). Harper's Biochemistry. USA: Prentice Hall, 1990; 317.

7. Ebadi M. Vitamin B6 and biogenic amines in brain metabolism. In: Sauberlich HE, Brown ML (ed). Human Vitamin B6 Requirement. Washington: National Acad of Sci, 1975; 129-61.

8. Coursin DB. Convulsive Seizures in infants with pyridoxine deficient diet. J Am Med Assoc 1954; 154:406-8.

9. Chung SH, Cox RA. Determination of pyridoxal phosphate levels in the brains of audiogenic and normal mice. Neurochem Res 1954; 8:1245-59.

10. Kouyoumdjian JC, Ebadi M. Anticonvulsant activity of muscimol and GABA against pyridoxal phosphate induced epileptic seizures. J Neurochem 1981; 36:251-7.

11. Kryzhanovski GN, Shandra AA. Effect of Diazepam, Carbamazepine, Sodium Valproate and their combination with vitamins on epileptic activity. Bull exp Biol Med (USA) 1986 April.

12. Tedeschi G, Cenraud B, Guyot M, Gomeni R, Morselli PL, Levy RH, Loiseau P. Influence of food on carbamazepine absorption. In: Gram L, Penny JK (ed). Advances in Epileptology. New York: Raven Press, 1981.

13. Miles $R$, Wong RKS. Single neurons can initiate synchronized population discharge in the CA3 region of the guinea pig hippocampus. Nature 1983; 304:371-3.

14. Hablitz JJ. Picrotoxin-induced epileptiform activity in hippocampus: role of endogenous versus synaptic factors. $J$ Neurophysiol 1984; 51:1011-27.

15. Benninger C, Kadis J, Prince DA. Extracellular calcium and potassium changes in hippocampal slices. Brain Res 1980; 187:165- 82.

16. Krnjevic K, Morris ME, Reiffenstein RJ, Ropert N. Depth distribution and mechanism of changes in extracellular $\mathrm{K}^{+}$ and $\mathrm{Ca}^{2+}$ concentrations in the hippocampus. Can J Physiol Pharmacol 1982; 60:1658-71. 